\title{
The Outcome of the ArtFrame Project, a Domain-Specific BIBFRAME Exploration
}

ARLIS/NA Conference, February 27, 2018

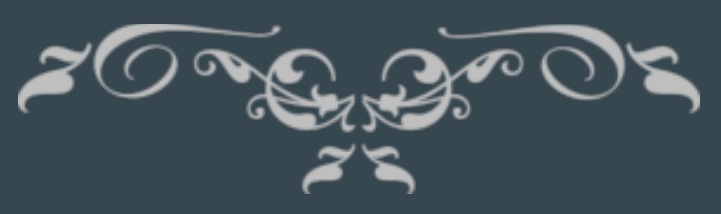

Amber Billey, Bard College

Marie-Chantal L'Ecuyer-Coelho, Bibliothèque et Archives nationales du Québec

Jason Kovari, Cornell University

Maria Oldal (Moderator), Morgan Library \& Museum

Melanie Wacker, Columbia University 


\section{Part 1: Background \& Motivation}




\section{Linked Data for Production}

Andrew W. Mellon Foundation funded

Columbia University

Cornell University

Harvard University

Princeton University

Stanford University

Library of Congress
Focus (selected):

- ontology extensions

- metadata production

- pipelines and workflows 


\section{LD4P Ontology Extensions}

ArtFrame

Cartographic

Moving Image

Performed Music

$\underline{\text { Rare Materials }}$ 


\section{Linked Data for Libraries - Labs}

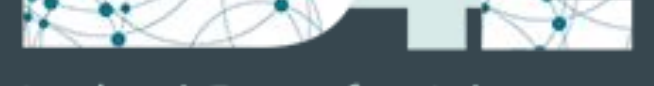

Andrew W. Mellon Foundation funded

Cornell University

Harvard University

Stanford University

University of Iowa
Focus (selected):

- VitroLib (RDF editor)

- Look-up services 


\section{Why Linked Data?}

Standardized technologies

Discovery-focused

Entity-driven

Interoperable beyond libraries 


\section{Standardized Technologies... Standardized Standards}

Ontology adoption varies widely

Library-domain ontologies : limited development 


\section{Current Status of Linked Data in Library Domain}

Ontology development

- BIBFRAME

- RDA-RDF

- VRA-RDF

- schema.org

- Myriad of additional ontologies

Challenge: subject domains 


\section{Current Status of Linked Data in Library Domain}

Prototyping \& experimentation

Limited in-production efforts

Lacking out-of-the-box solutions 


\section{Gall to Mobilize}

Need more training

Need more collaboration

Need more tool development

Need more practitioners 


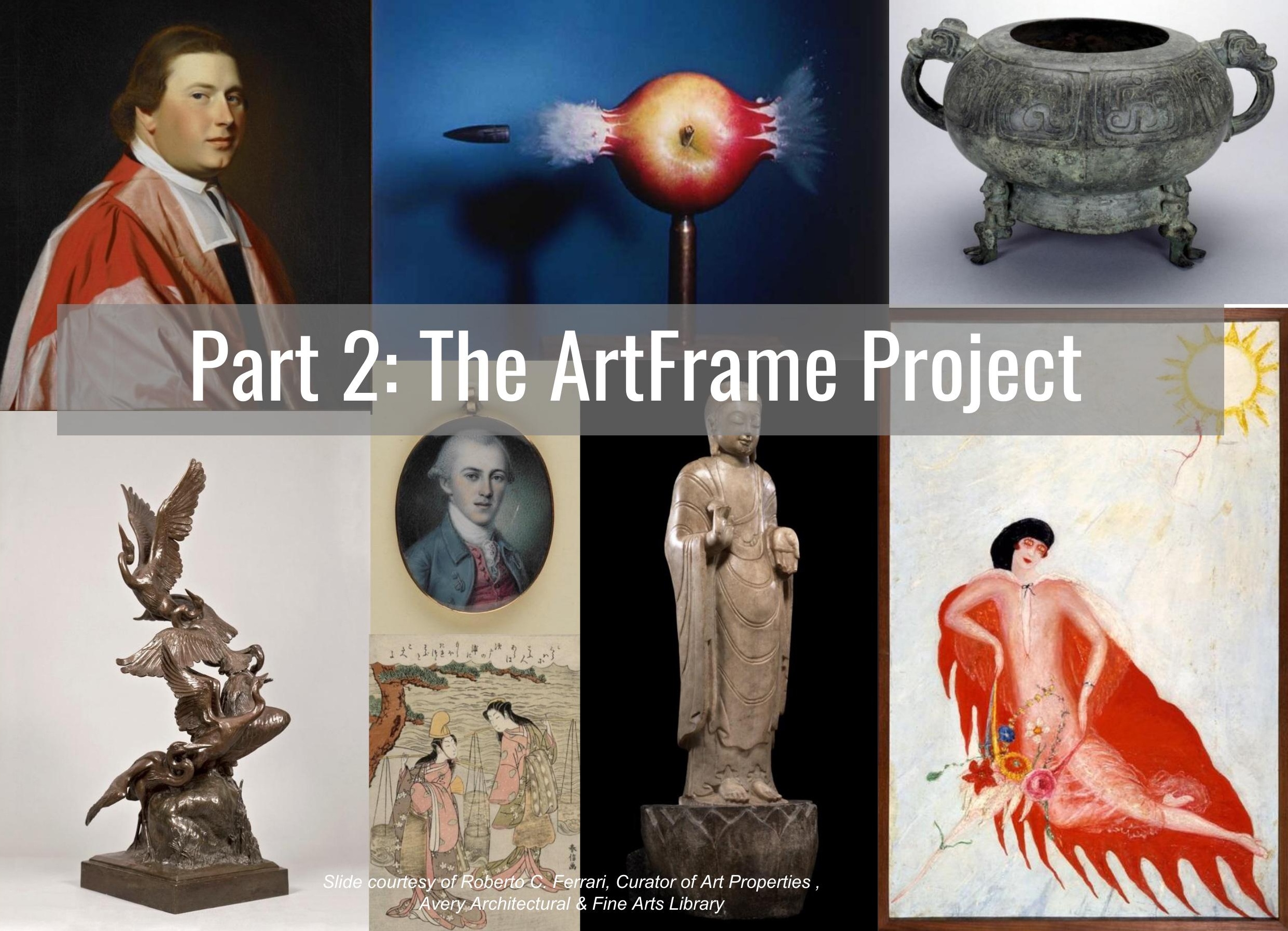




\section{Why Test BIBFRAME with Art Objects?}

- Many libraries own art objects

- Art objects have been described in MARC

- Larger institutions often have libraries as well as museums -lack of communication between the two

- BIBFRAME is supposed to work with "various content models" and accommodate "different needs for resource descriptions"

(Library of Congress (2012). Bibliographic Framework as a Web of Data. Page 15) 


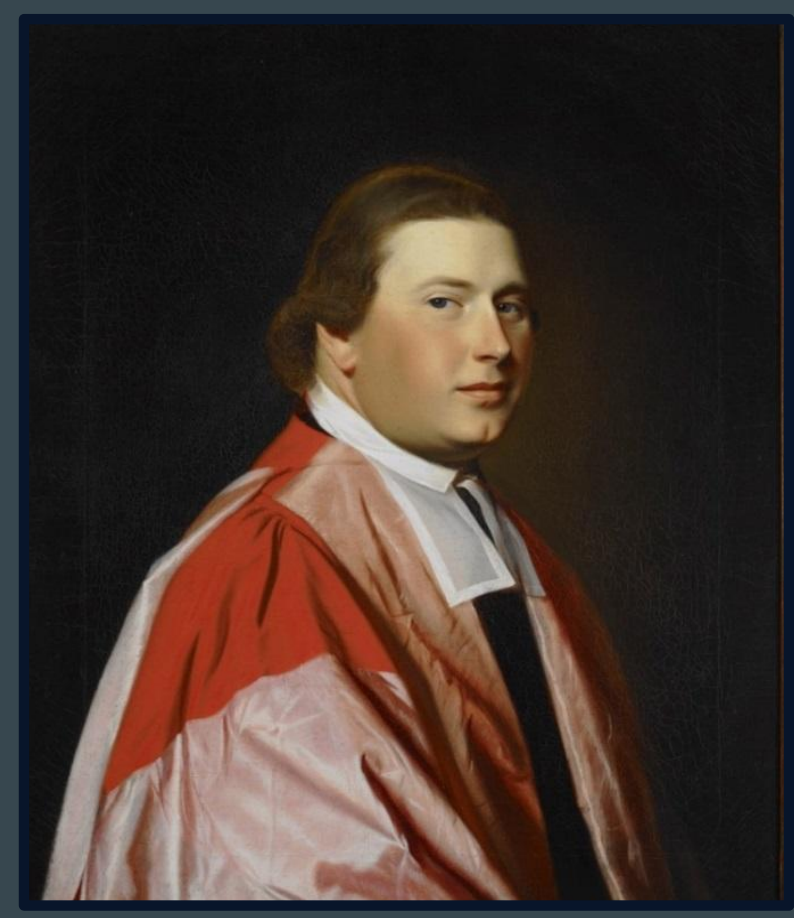

John Singleton Copley Portrait of Myles Cooper ca. 1768 , oil on canvas

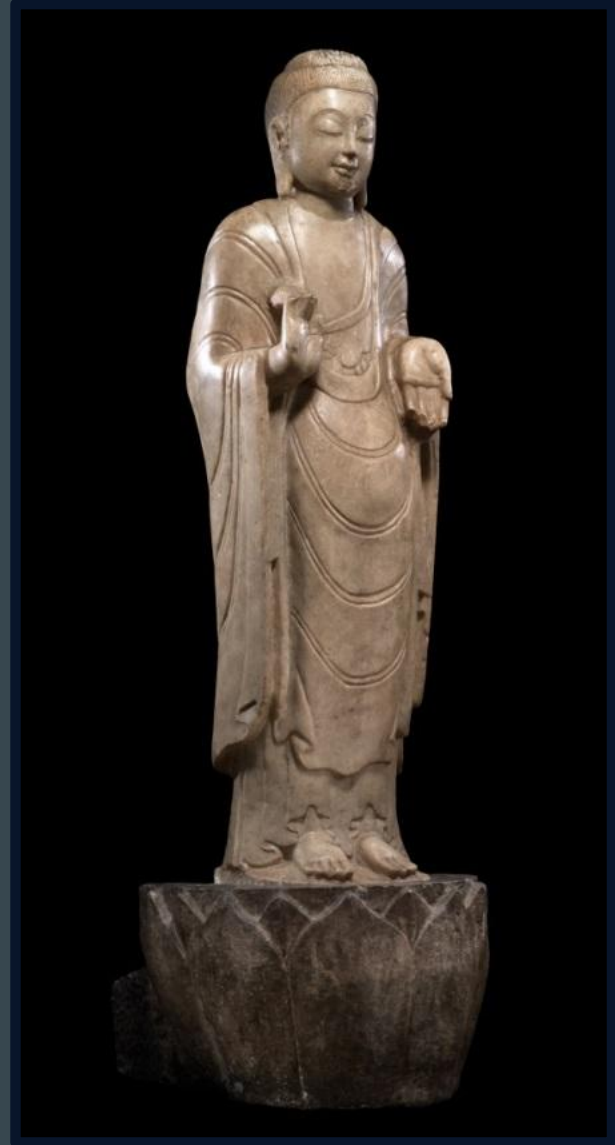

Standing Buddha, China Northern Qi dynasty (550-577), limestone with marble base

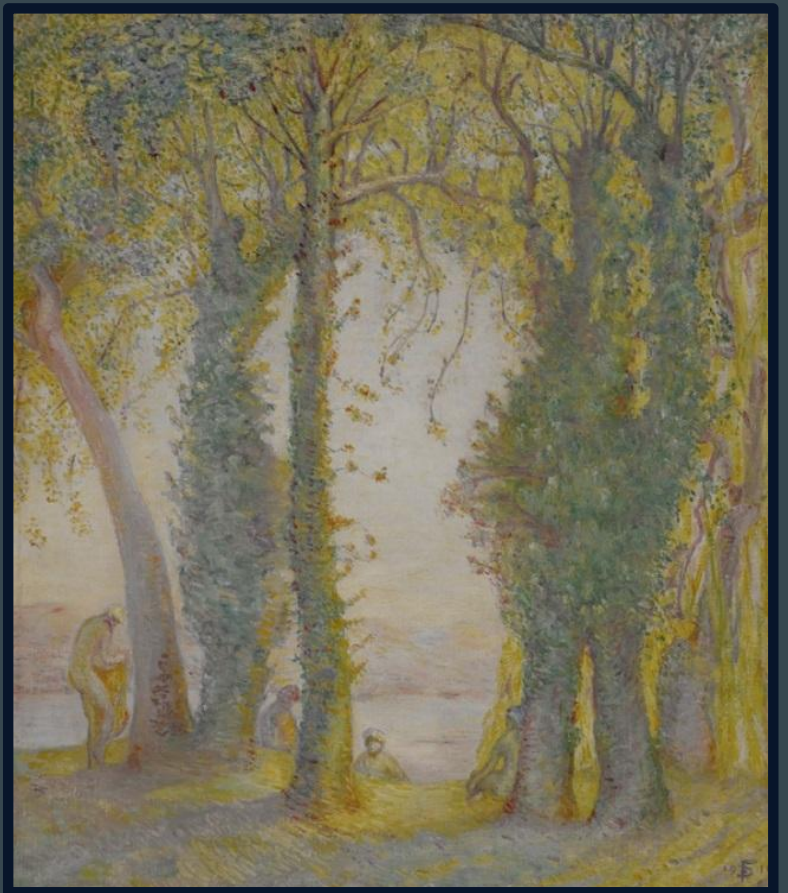

Florine Stettheimer Landscape No. 2 with Bathers 1911, oil on canvas

Slide courtesy of Roberto C. Ferrari, Curator of Art Properties and Margaret Smithglass, Registrar and Digital Content Librarian, Avery Architectural \& Fine Arts Library 


\section{The Art Properties Collection}

- Art collection owned by Columbia University

- $12,000+$ works of art -- largely from gift or bequest

- Works are regularly loaned to exhibitions worldwide and displayed in selected areas on campus

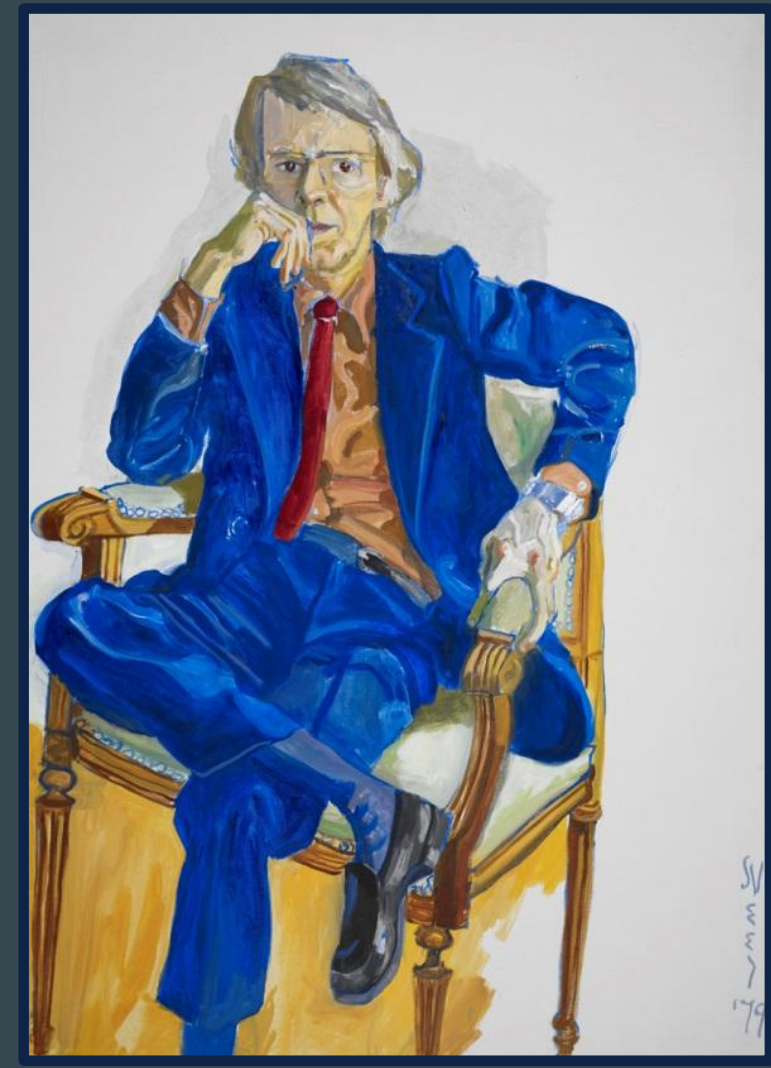

- Art Properties home page: http://library.columbia.edu/loca Alice Neel Portrait of Jack Beeson 1979 tions/avery/art-properties.html 


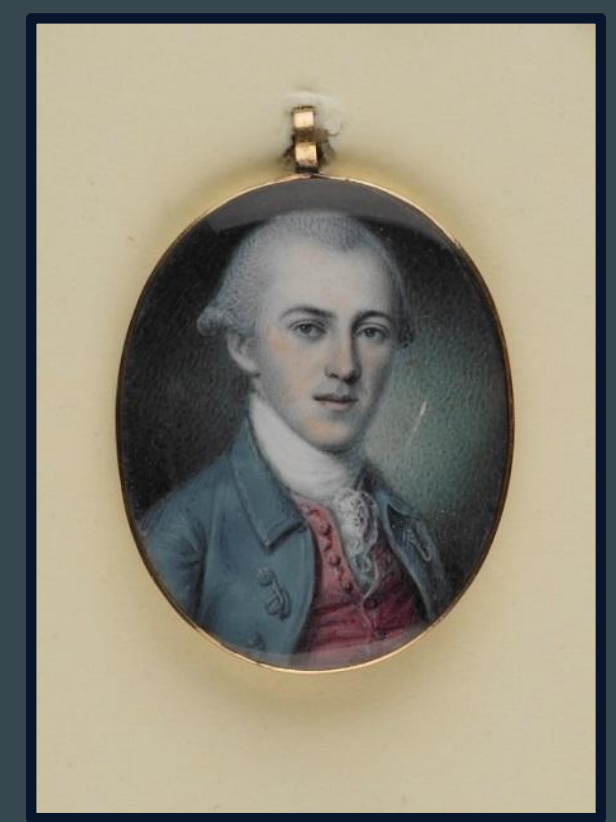

Charles Willson Peale Portrait Miniature of Alexander Hamilton, c.1780 watercolor on ivory

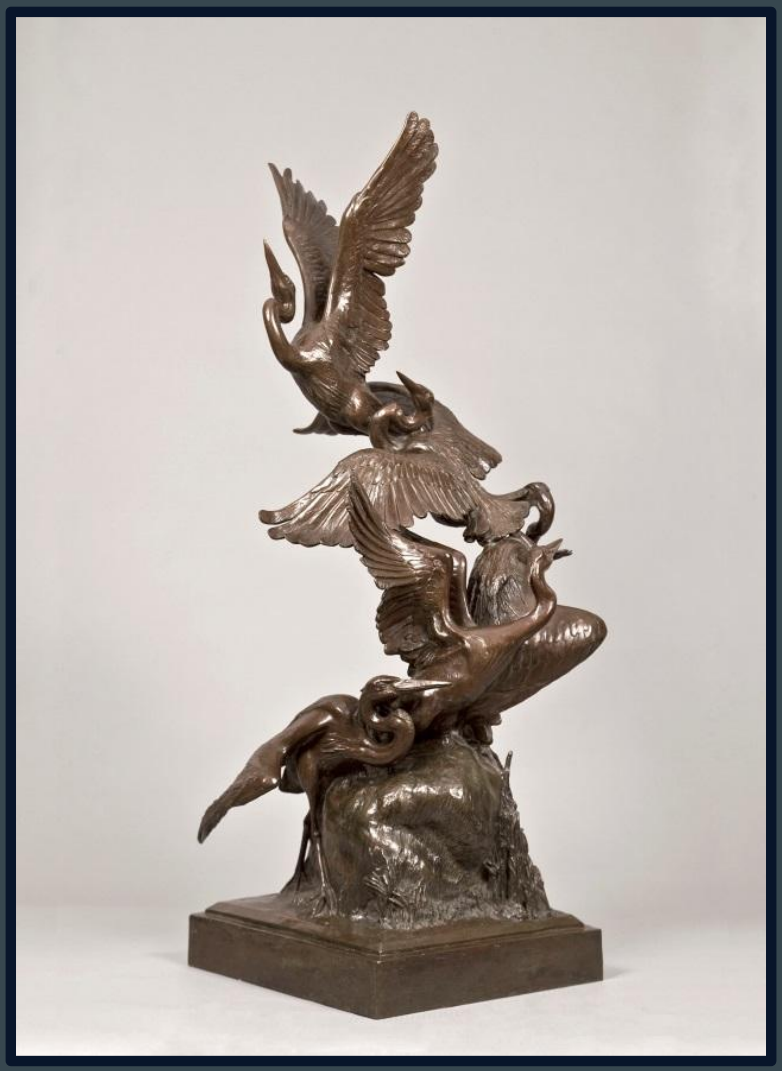

Anna Hyatt Huntington Cranes Rising, 1934, bronze

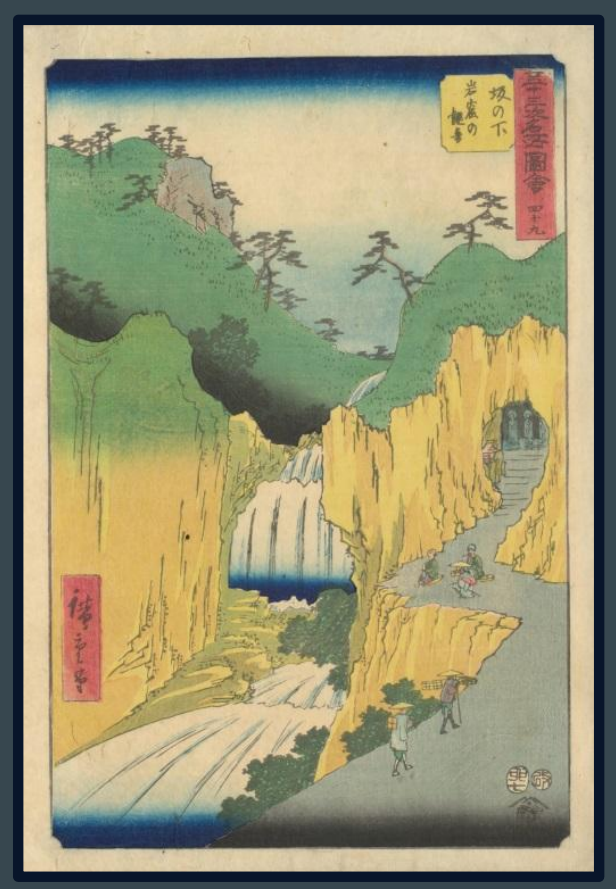

Hiroshige

The Cave Shrine of Kannon Japan, Edo period 1855 , woodblock print 
( ) (i) https://clio.columbia.edu/catalog/12003862

Most Visited Getting Started II Desk Tracker de Columbia University A... An Art Properties |Colum... Public Outdoor Sculpt...

J Columbia Spectator Ar...

d. COLUMBIA UNIVERSITY LIBRARIES / INFORMATION SERVICES .

\section{CLIO}

Art Properties

Location

Q

Advan

« Back to Results | «Previous | 2 of $9,618,512$ | Next »

Print Email Send to Phone Add to My Saved List Export - Display In - Requests - Start Over

\section{Portrait of Frederick A. P. Barnard (1809-1889)}

Creator Johnson, Eastman, 1824-1906, artist.

Title Portrait of Frederick A. P. Barnard (1809-1889).

Produced United States, 1886.

Physical 1 painting; $49 \times 391 / 2$ in. $(124.4 \times 100.3 \mathrm{~cm})$

Properties Oil on canvas.

Inscription Signed and dated lower left: E. Johnson / 1886.

Notes Plaque on frame: FREDERICK A. P. BARNARD, D.D., LITT LL.D. / A.B. Yale College 1828 / President of the University of Mississippi 1856-1861 / President of Columbia College 1864-1889.

Credit Line Commissioned by the Trustees, 1886

Subjects Barnard, Frederick A. P. (Frederick Augustus Porter), 1809-1889, depicted

Subjects (Genre) Paintings (visual works) $>$ American $>19$ th century Portraits $>$ American $>19$ th century.

Format

Bookmark As https://clio.columbia.edu/catalog/12003862

\section{[] Art Work (Original)}

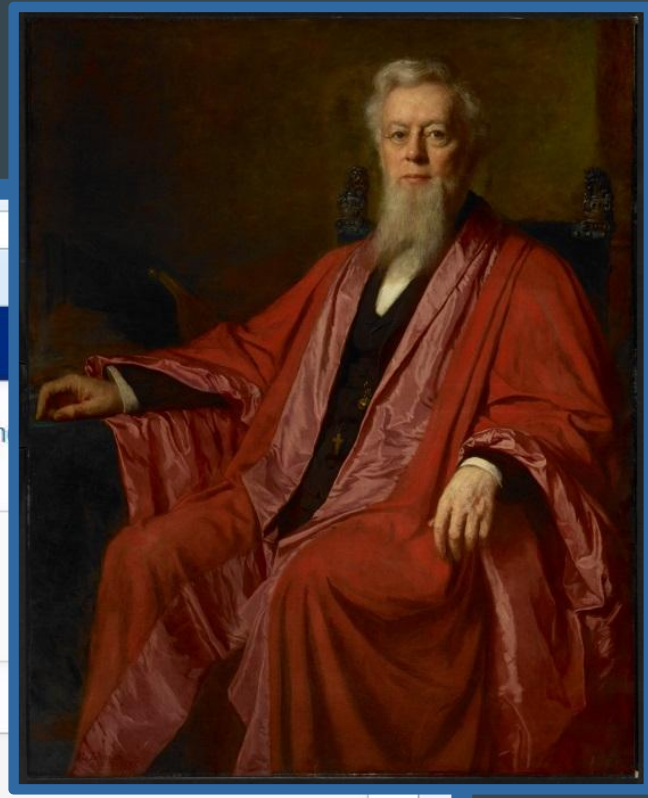

Available from:

- Avery Art Properties - By appt. (Non-Circulating)

Today's Hours: $9 \mathrm{am}$ - 9pm

By appointment only. See the Avery Art Properties webpage Call Number: C00.0110

\begin{tabular}{|c|c|c|}
\hline Virtual Shelf Browse & Show & Hide \\
\hline
\end{tabular}




\section{Original ArtFrame Timeline}

Project start: March 2016

Months 1-3: Evaluation of BIBFRAME and existing art-focused ontologies, surveying of existing art linked data developments

Month 4: Use case development

Months: 5-8: Focus on ontology development and data modeling

Months: 9-11: Profile development

Months: 11-13: Data transformation/creation

Months: 14-16: Address local workflow

Months: 18-21: Evaluation of project results and written summary of the findings.

Months: 22-24: Document and share project finding via a web site, public presentations at conferences, etc.

Original project end date: March 2018 


\section{Real Timeline}

Project start: March 2016

Months 1-3: Evaluation of BIBFRAME and existing art-focused ontologies, surveying of existing art linked data developments

Month 4: Create Community Group, Use case development

Months 5-8: Use case development, analysis of use cases, prioritization, identify ontology requirements

Months 9-19: Modelling the identified areas (still ongoing), creation of OWL files Months 19-22: Creation of OWL files, Application profiles, test descriptions Months 23-27: Finalizing the OWL files, finalizing the application profiles, original cataloging in VitroLib, spreadsheet conversion using KARMA, sharing of project results

Project end date: Extended through June 2018 


\section{Documentation}

\section{Linked Data for Production (LD4P) Wiki}

https://wiki.duraspace.org/pages/viewpage.action?pageId=74515

$\underline{029}$

ArtFrame-RareMat GitHub

https:/github.com/LD4P/ArtFrame-RareMat/tree/master 


\section{Columbia Team}

- Amber Billey (Metadata Librarian, 2015-October 2017)

- Roberto Ferrari (Curator of Art Properties)

- Kate Harcourt (Director, Original and Special Materials

Cataloging)

- Erin Petrella (Metadata Assistant, 2015-September 2016)

- Robert Rendall (Principal Serials Cataloger)

- Margaret Smithglass (Registrar and Digital Content Librarian, Avery Library)

- Project Coordinator: Melanie Wacker (Metadata Coordinator) 


\section{Community \& Extension Group}

- The Art Extension Group (interested members of the art and art library community)

- Library of Congress Prints \& Photographs Division

- Sterling and Francine Clark Art Institute

- Morgan Library \& Museum

- Cataloging Advisory Committee of ARLIS/NA (May 2016)

- Amber Billey (Bard College, formerly Columbia) 


\section{Collaboration with RareMat}

- Happenstance lead to cooperation and collaboration

- Many similar and overlapping issues

- Condition and conservation, exhibitions, custodial history, awards, accession numbers, etc

- Through the projects leads at Columbia and Cornell, the two groups began working together to define and model commonalities

- Two in-person meetings and several joint working groups resulted in common pattern recommendation documents and ontological modeling with OWL files 


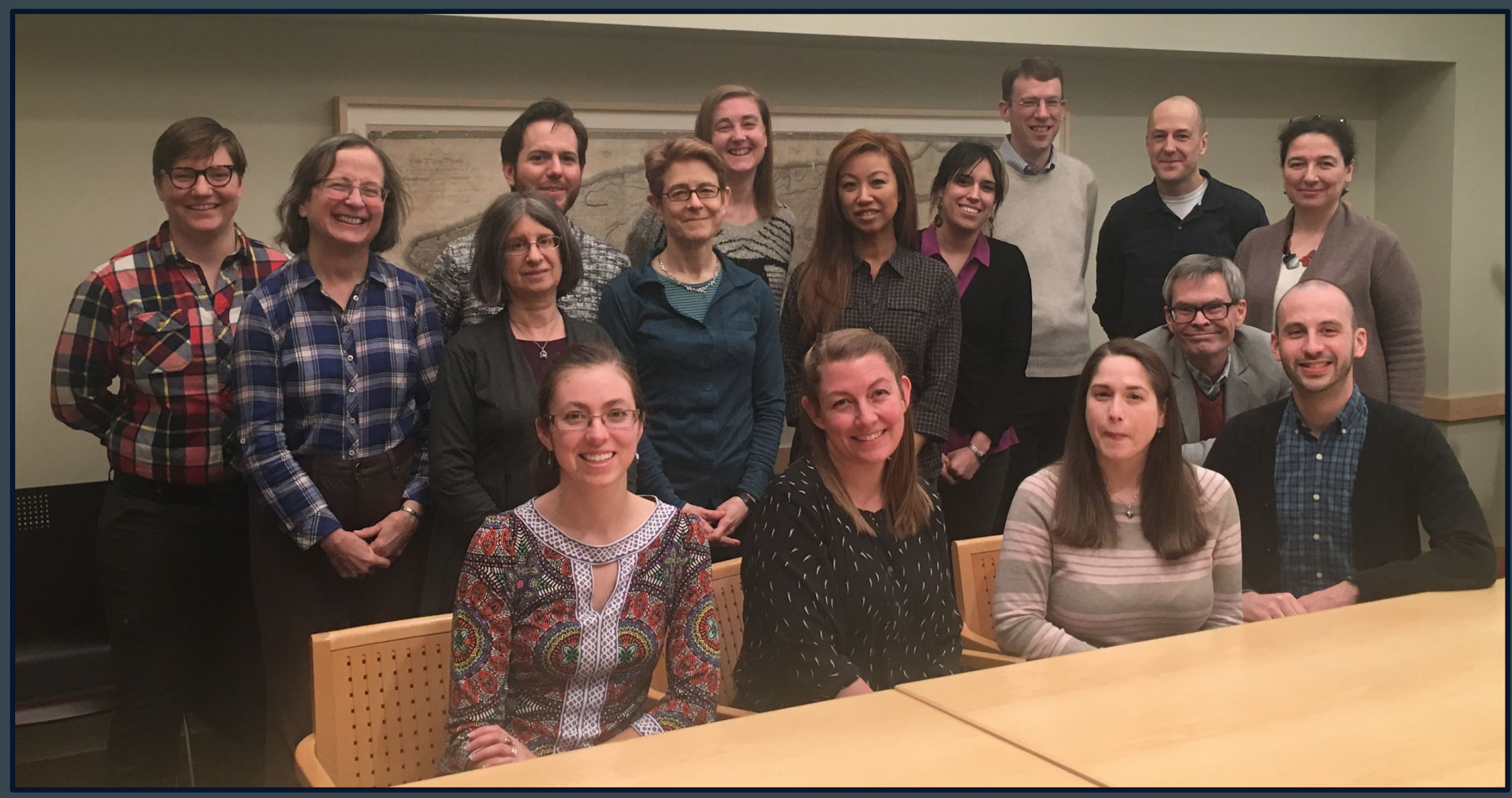

First in Person Meeting 2017: ArtFrame \& RareMat 


\section{Accomplishments}

- Literature Review

- Focus on descriptive cataloging of art objects in libraries

- Use Cases

- 52 Use Cases defined by the group

- Organized into 12 groupings

- Use Analysis and Entity Modeling

- Modeling

- Creating OWL files 


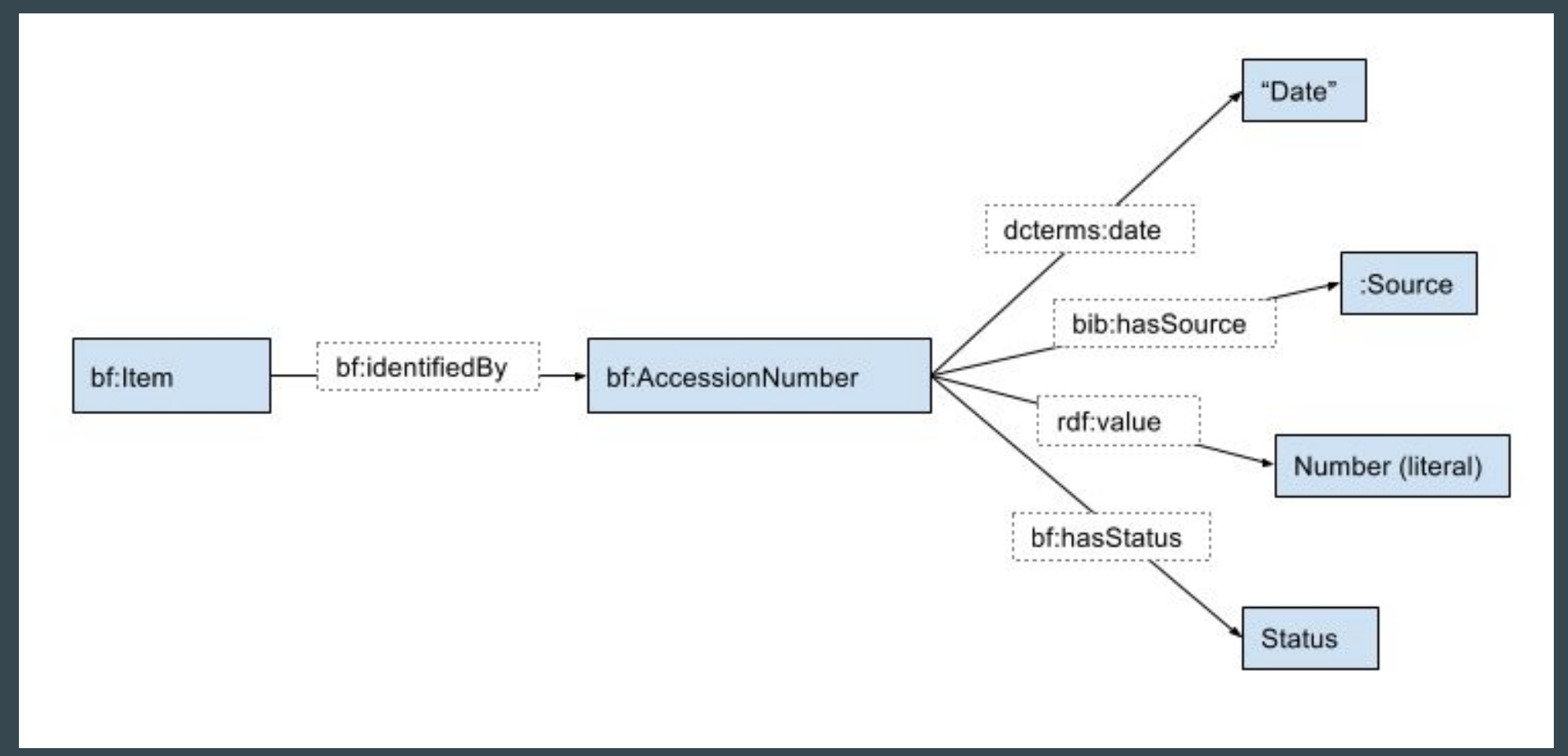

Model 1: Accession Number 


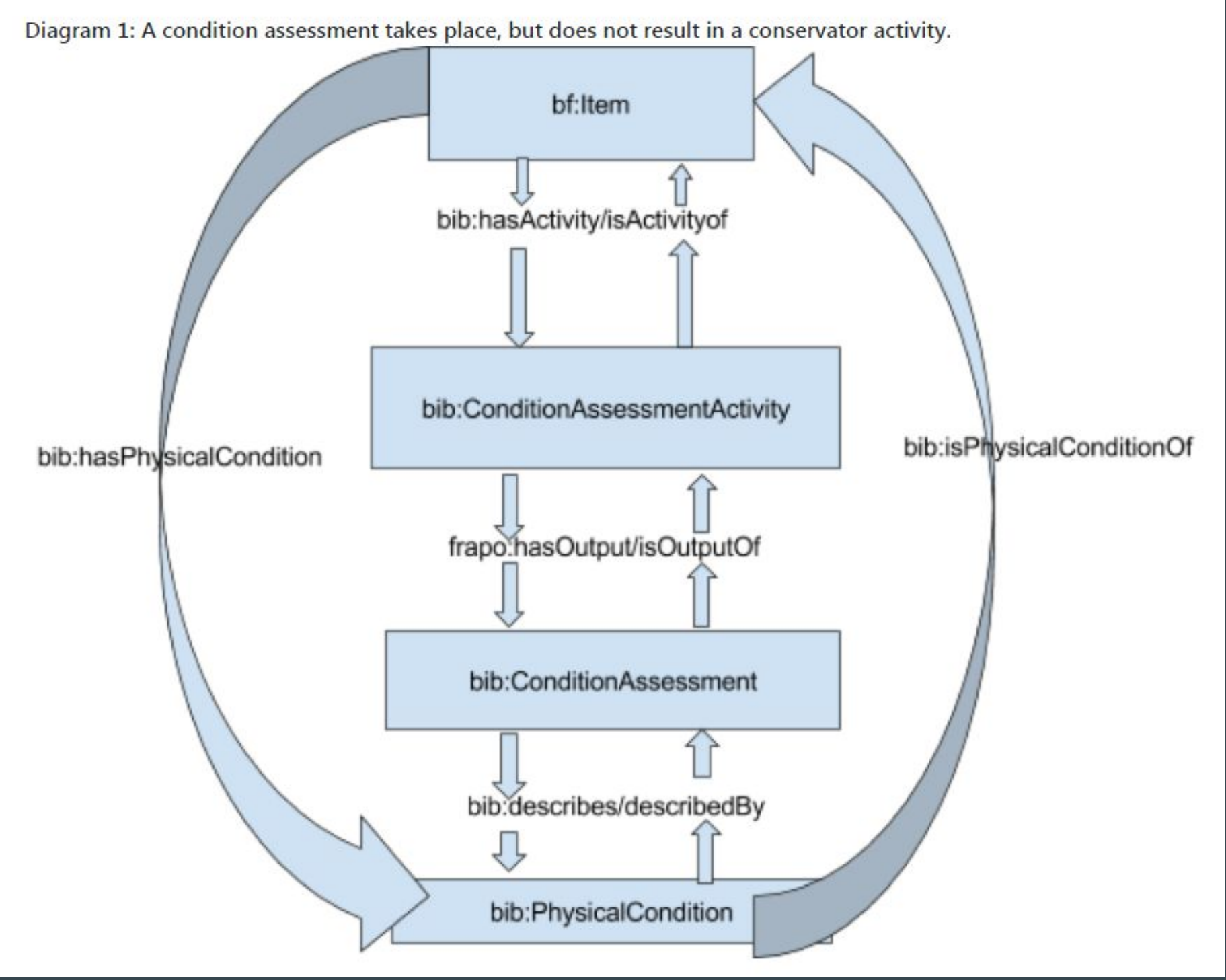

\section{Model 2: Activities Relating to Physical Condition}


Diagram 3: One condition assessment describing one physical condition leading to one conservator activity resulting in a new physical condition.

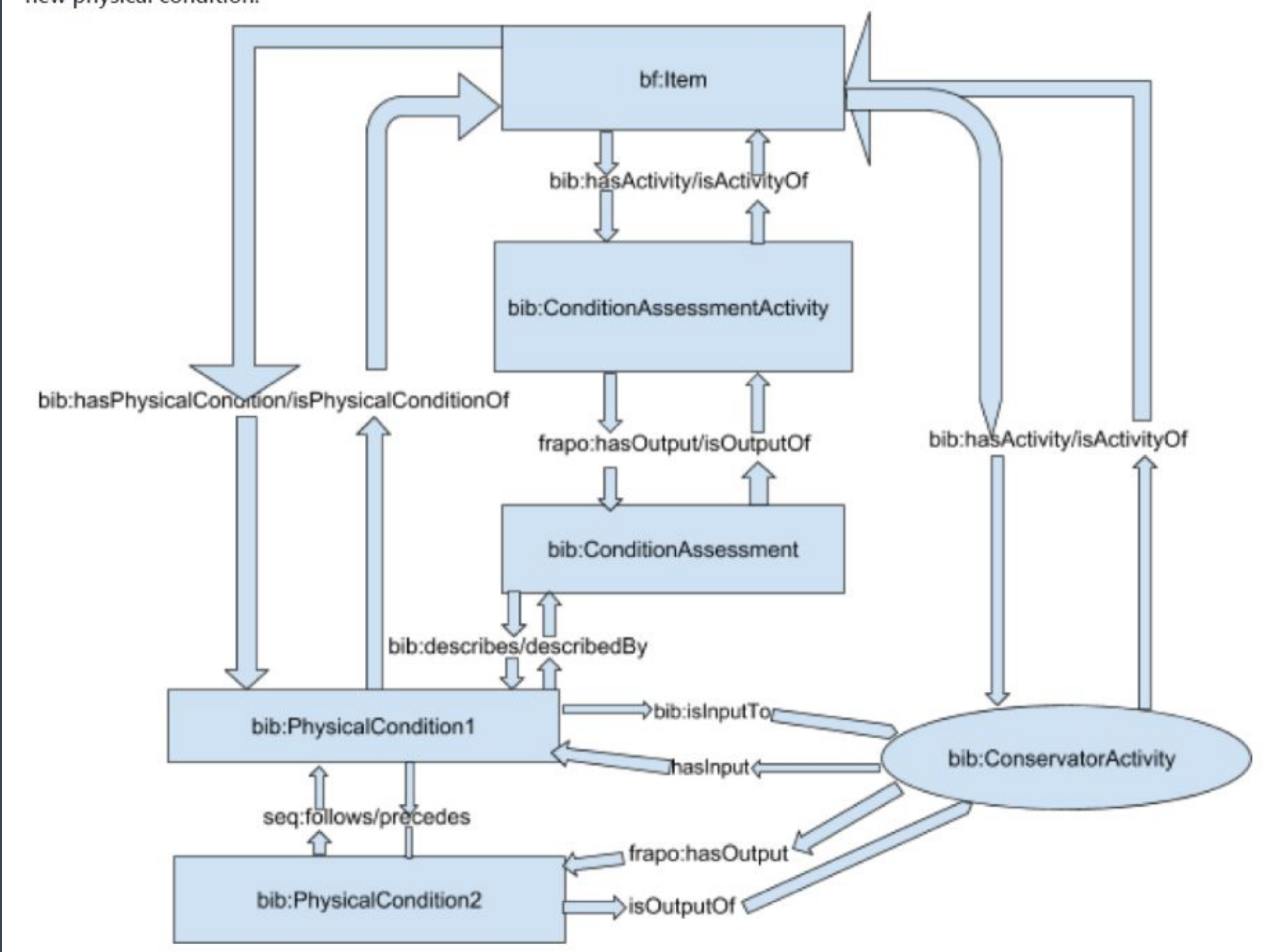

\section{Model 2: Activities Relating to Physical Condition}




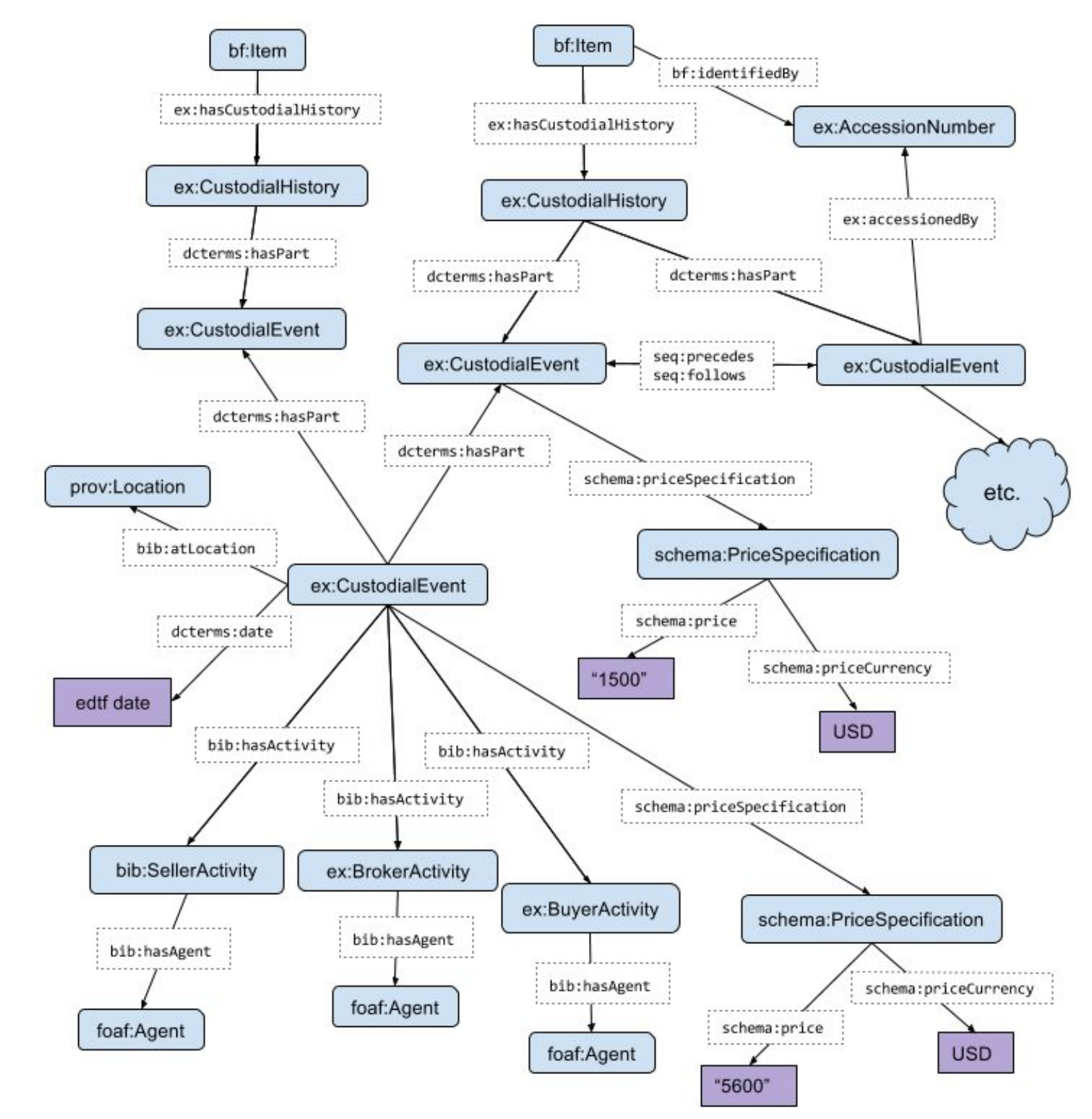

\section{Model 3: Custodial History}




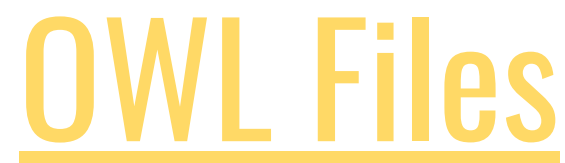

- ArtFrame and RareMat members were given training on how to write OWL files

- Groups and individuals have spent the last several months creating and publishing OWL files

- Some OWL files are already published on GitHub, but most are still in development. The rest will likely be published in early March.

<skos:scopeNote>Refers to the transfer of ownership through auction, rather than the auction in which that occurs.</skos:scopeNote> <skos:scopeNote>Typical associated Activities: BuyerActivity, bib:SellerActivity, BrokerActivity.</skos:scopeNote> 


\section{Tools}

- Data Integration

- Karma

- Editors

- VitroLib

○ Cedar $+\underline{\text { BiblioPortal }}$

- BIBFRAME Editor

- Converter Tools

- MARC to BIBFRAME Converter

- MARC to bibliotek-o Converter 


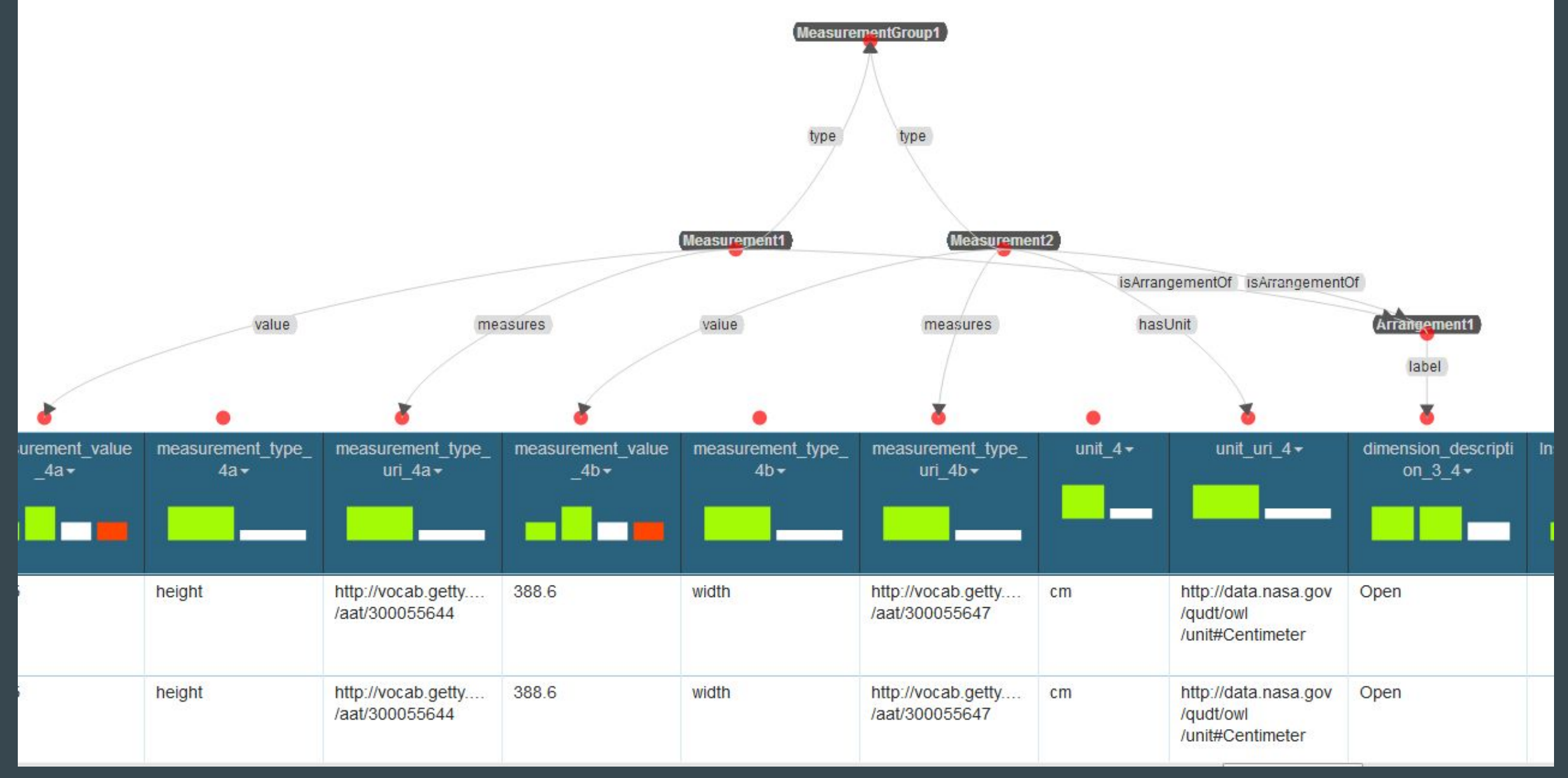

\section{Karma: Measurements Model}


Catalog a new resource ${ }^{\text {? }}$

Work +

\section{Statistics}

$$
\begin{aligned}
& 104 \\
& \text { Works }
\end{aligned}
$$

\section{$\underline{\text { VitroLib :: Home Screen }}$}




\section{DQ4L \\ Linked Data for Libraries}

\section{Home Works Instances Items People Organizations}

New Work

Title *

Type *

Audio

Language *

English

$\hat{\sim}$

Author or Other Role *

Author $\quad$ -

Select an existing Entity or create a new one.

LC Subject Heading

Select an existing Entity or create a new one.

\section{VitroLib : New Work editor screen}




\section{D4t \\ Linked Data for Libraries}

\section{Home Works Instances Items}

\section{Admin Panel Edit this individual}

Resource URI: http://vitrolib.ld4p.library.cornell.edu/individual/n4392

\section{Beast Epic $\mid$ Audio disc $\mid$ (instance) $\mathfrak{O}$}

Instance Agent Information Measurements Audio Instance Characteristics Other View All

\section{Preferred title}

Preferred title is a faux property of bibliotek-o: a BIBFRAME 2 Ontology Extension:hasPreferredTitle (object property); order in group: 0; display level: all users, including public; update level: all users who can log in; publish level: all users, including public

\section{VitroLib : Instance example}




\section{Open Questions}

- Hosting

- Where will these ontologies live on the Web?

- Maintenance

- How will they be maintained, edited, and managed?

- Collaborations

- Future and continued?

- Testing

- How to test the ontologies and the new RDF data?

- Tooling

- Do the current tools meet our needs? Do we need custom tools?

- Adoption

- How do we promote adoption? 


\section{Part 3:}

\section{The Cataloging Advisory Committee of ARLIS/NA and ARTFrame \\ .}

Marie-Chantal L'Ecuyer-Coelho

Cataloguing Librarian for Graphic Materials

Cataloguing Directorate for the Heritage Collections

Bibliothèque et Archives nationales du Québec 


\section{CAC's involvement}

\section{ArtFrame Project Team :}

- Columbia's LD4P team

- The Art Extension Group (interested members of the art and art library community)

a. Library of Congress Prints \& Photographs Division

b. Sterling and Francine Clark Art Institute

c. Cataloging Advisory of ARLIS/NA (May 2016)

Art Institute of Chicago / Bard College / Bibliothèque et Archives nationales du Québec (BAnQ) / Metropolitan Museum of Art / Pratt Institute / Sterling and Francine Clark Art Institute / Morgan Library \& Museum 


\section{Use case development}

CAC expertise

- Familiar with the various kinds of cultural objects found in art institutions (prints, photographs, drawings, paintings, artists' books, sculpture, installations, manuscripts, handicrafts, etc.)

- Sensitive to the specific needs of end-users interested in art resources

- Aware of the limitations of our data for retrieval purposes

- Familiar with the cataloguing standards in use in libraries and museums (differences between the bibliographic tradition and the cataloging practices of museums and visual resources centers) 


\section{Use cases submitted by CAC members}

- Discover related works held by different institutions

- Find images showing the different states of an art print

- Find images containing visual references to well-known artworks

- Find artworks that are typical of a given style or artistic school

- Search and sort artworks by colour palette, medium, or production methods

- Find information about the weight of art objects from a given collection

- Discover artworks sold at a particular auction sale / by a particular auction house 


\section{Analysis and modelling : Style in MARC 21}

=100 1\\$aLordon, Pierre Jérôme, \$d1780-1838, \$eartist.

=245 10 \$aAtala et Chactas :\$b"A la clarté de la lune, j'entrevois une grande figure blanche penchée sur moi, occupée à dénouer silencieusement mes liens ..."/\$cLordon delt. ; J.P. Simon, scupt.

=264 \1 \$aA Paris : \$bchez Ostervald l'ainé, rue de la Verrerie, no. 14, ou rue Moussy, no. 7, \$c[between 1801 and 1810?]

$[\ldots]$

$=5208 \backslash$ \$aEarly romantic artprint depicting Atala as she releases Chactas from the ties that hold him against a column; an Indian is asleep on the other side of the pillar.

$[\ldots]$

=600 10 \$aChateaubriand, François-René, \$cvicomte de, \$d1768-1848. \$tAtala.

$=650 \backslash 0$ \$aNatchez Indians\$zLouisiana.

$=650$ \0 \$aAtala (Fictitious character)

$=650 \backslash 0$ \$aChactas (Fictitious character)

$=655 \backslash 7$ \$aEtchings $\$ x F r e n c h \$ y 1800-1810 . \$ 2$ gmgpc

$=7001 \backslash$ \$aSimon, John Peter,\$d-approximately 1810 , \$eetcher.

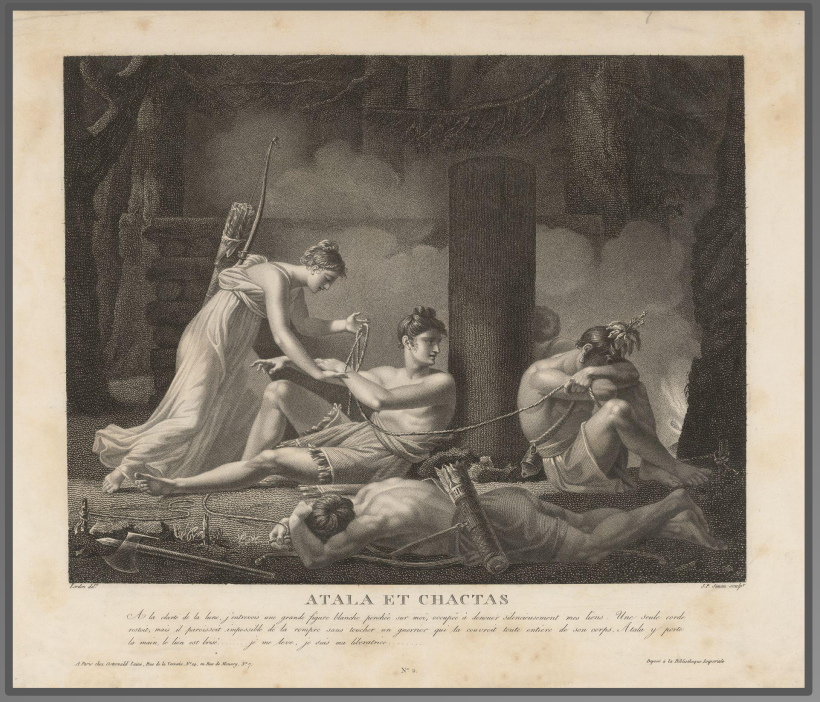

Public domain (BAnQ numérique) 


\section{Analysis and modelling : Style in BIBFRAME}

$<b f:$ summary $>$

$\langle$ bf : Summary>

rdfs: label $>$ Early romantic artprint depicting Atala as she releases Chactas from the ties that hold him against a column; an Indian is asleep on the other side of the pillar.</rdfs: label>

$</$ bf : Summary $>$

$</$ bf : summary $>$ 


\section{Analysis and modelling : Style in BIBFRAME}

<bf: note>

<rdf:Description>

<rdf:type rdf:resource="http://id.loc.gov/ ontologies/bibframe/Note"/>

<rdfs: label>Early romantic artprint depicting Atala as she releases Chactas from the ties that hold him against a column; an Indian is asleep on the other side of the pillar. $</$ rdfs: label $>$

$</$ rdf:Description $>$

$</$ bf: note $>$ 


\section{Analysis and modelling : Style in VRA/RDF}
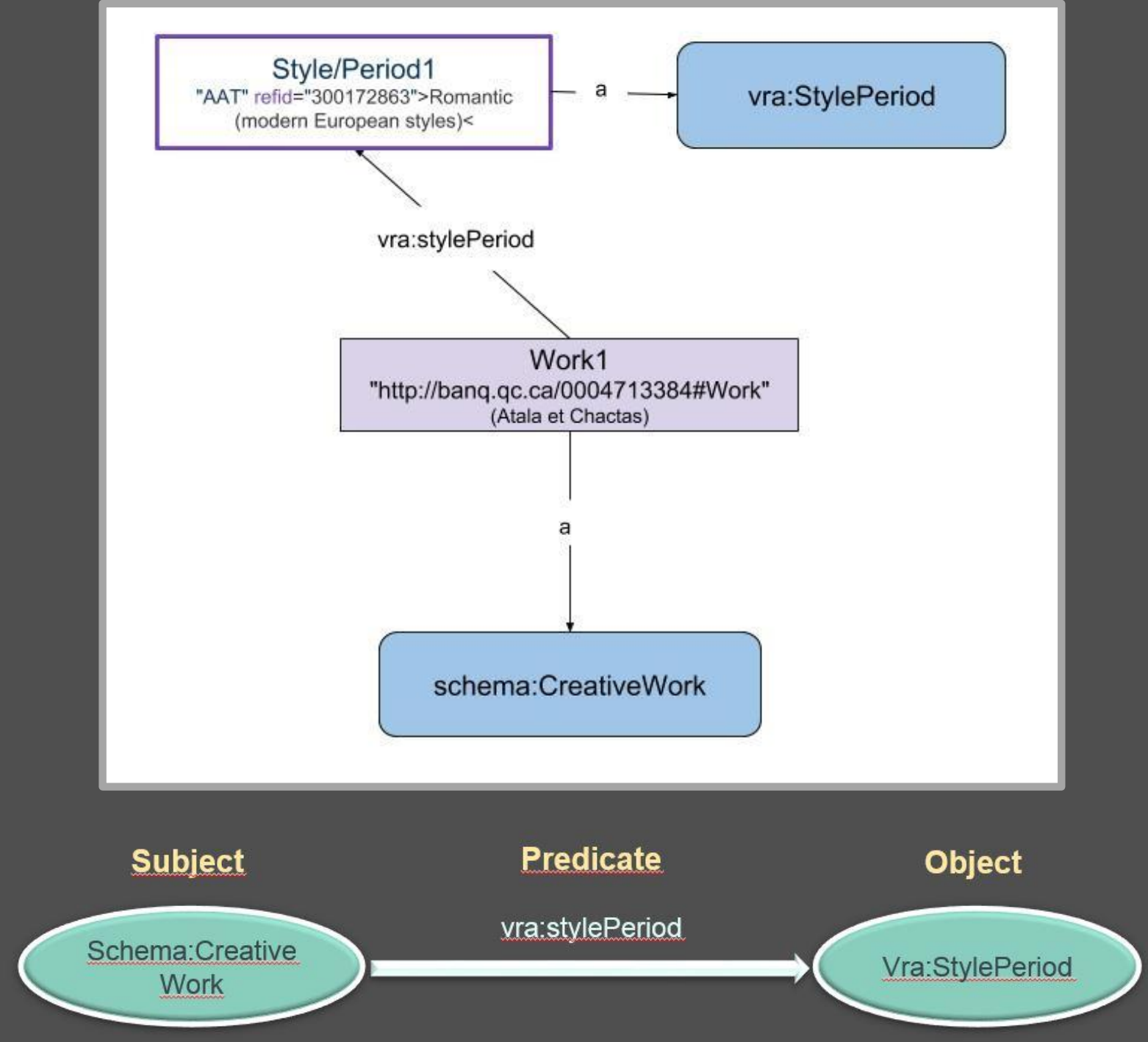


\section{ArtFrame recommendation for Style}

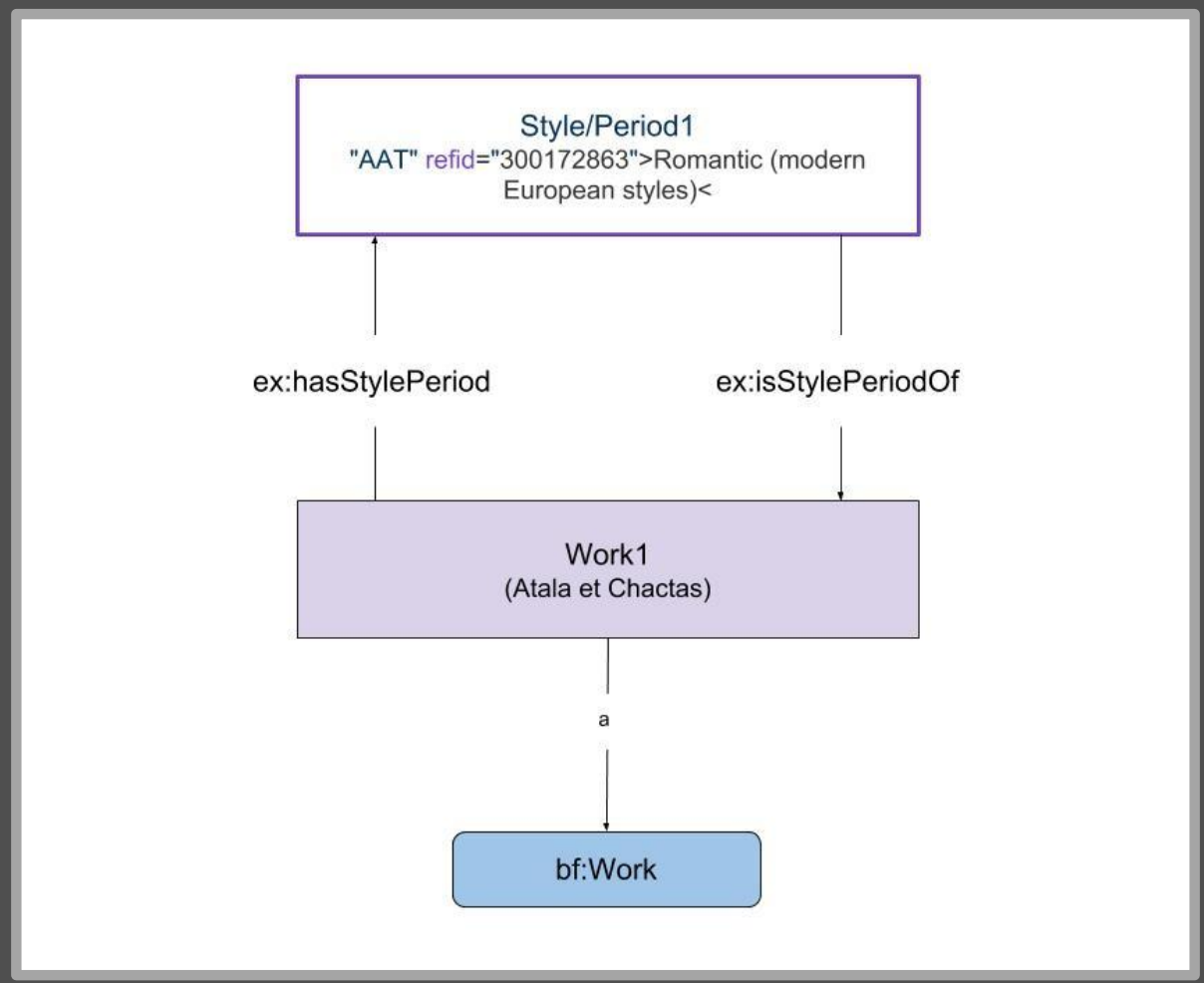

\section{ex:hasStylePeriod (Object Property)}

URI: TBD

Label: has style/period

Definition: A resource's relationship to a style/period it represents.

Domain: unspecified

Range: unspecified

Inverse: ex:isStylePeriodOf

\section{ex:isStylePeriodOf (Object Property)}

URI: TBD

Label: is style/period of

Definition: A style/period's relationship to a resource representing it.

Domain: unspecified

Range: unspecified

Inverse: ex:hasStylePeriod

:work1 a bf:StillImage ;

bf:title :title ;

ex:hasstylePeriod <http://vocab.getty.edu/aat/300172863> .

:title rdf:value "Atala et Chactas" . 


\section{Importance of item-level information (Binding Model)}

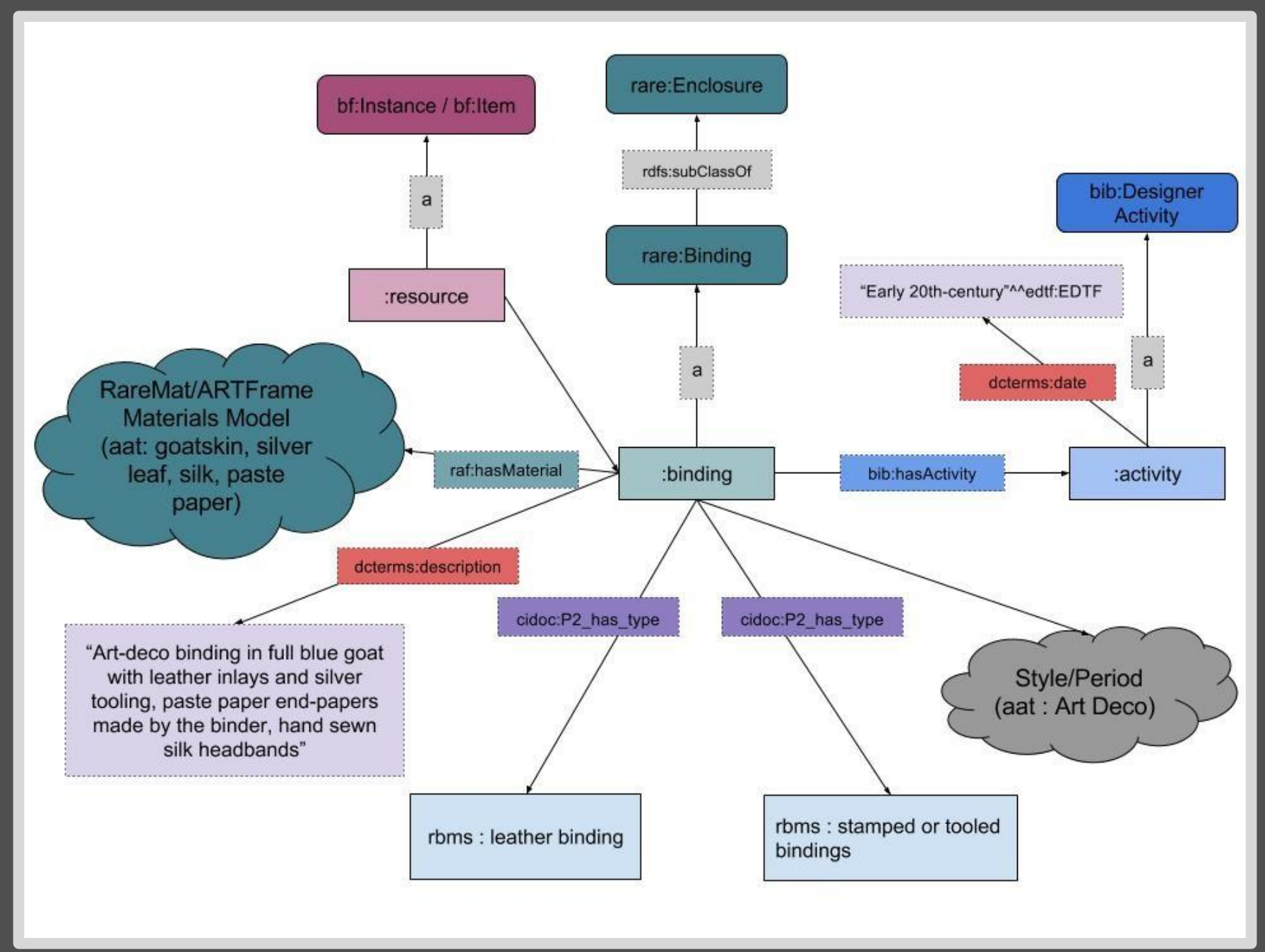




\section{BIBFRAME 2.0 multi-level model}

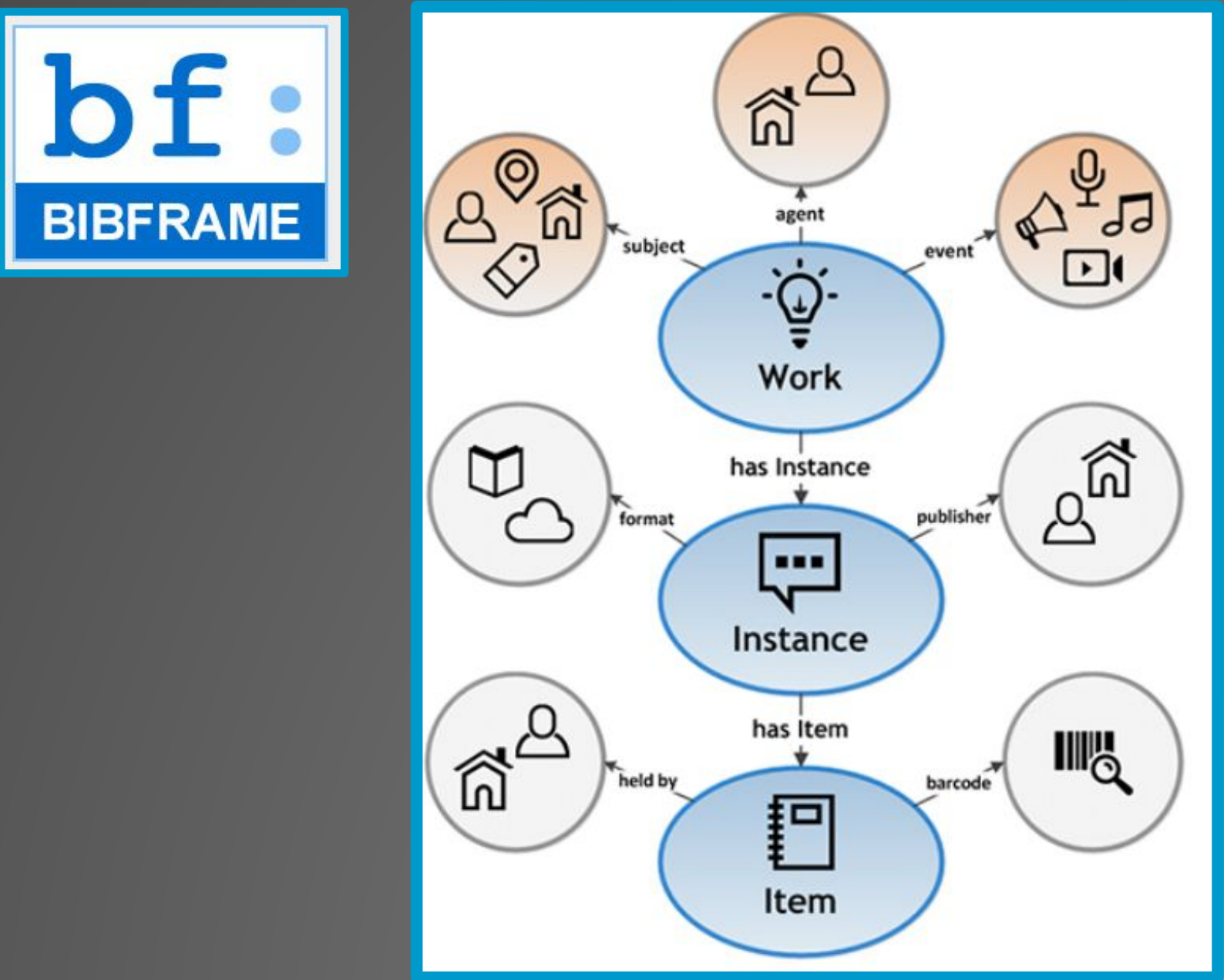

https://www. loc.gov/bibframe/docs/bibframe2-model. html 


\section{Color-content in BIBFRAME 2.0}
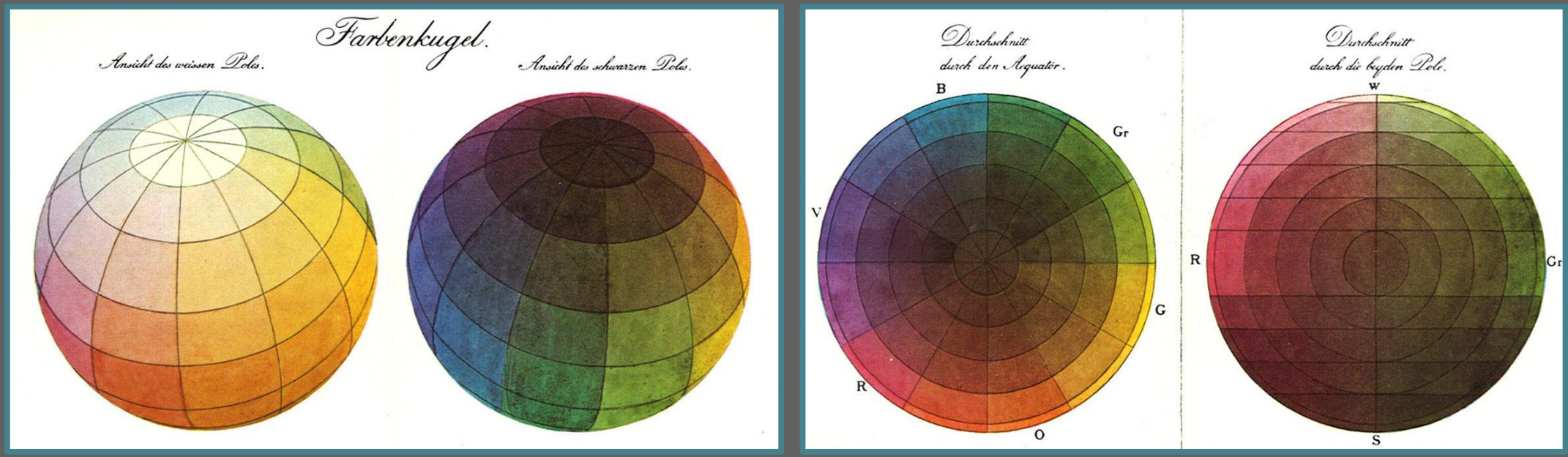

Public domain (Wikimedia Commons)

<owl:ObjectProperty rdf:about="http://id.loc.gov/ontologies/bibframe/colorContent"> <rdfs:range rdf:resource="http://id.loc.gov/ontologies/bibframe/ColorContent"/> <skos:definition>Color characteristics, e.g., black and white, multicolored.</skos: definition>

<rdfs:comment>Used with Work or Instance</rdfs:comment>

<rdfs: label>Color content</rdfs: label>

<dcterms : modified>2016-04-21 (New)</dcterms:modified>

$</$ owl: ObjectProperty> 


\section{Entity-level for colour content}

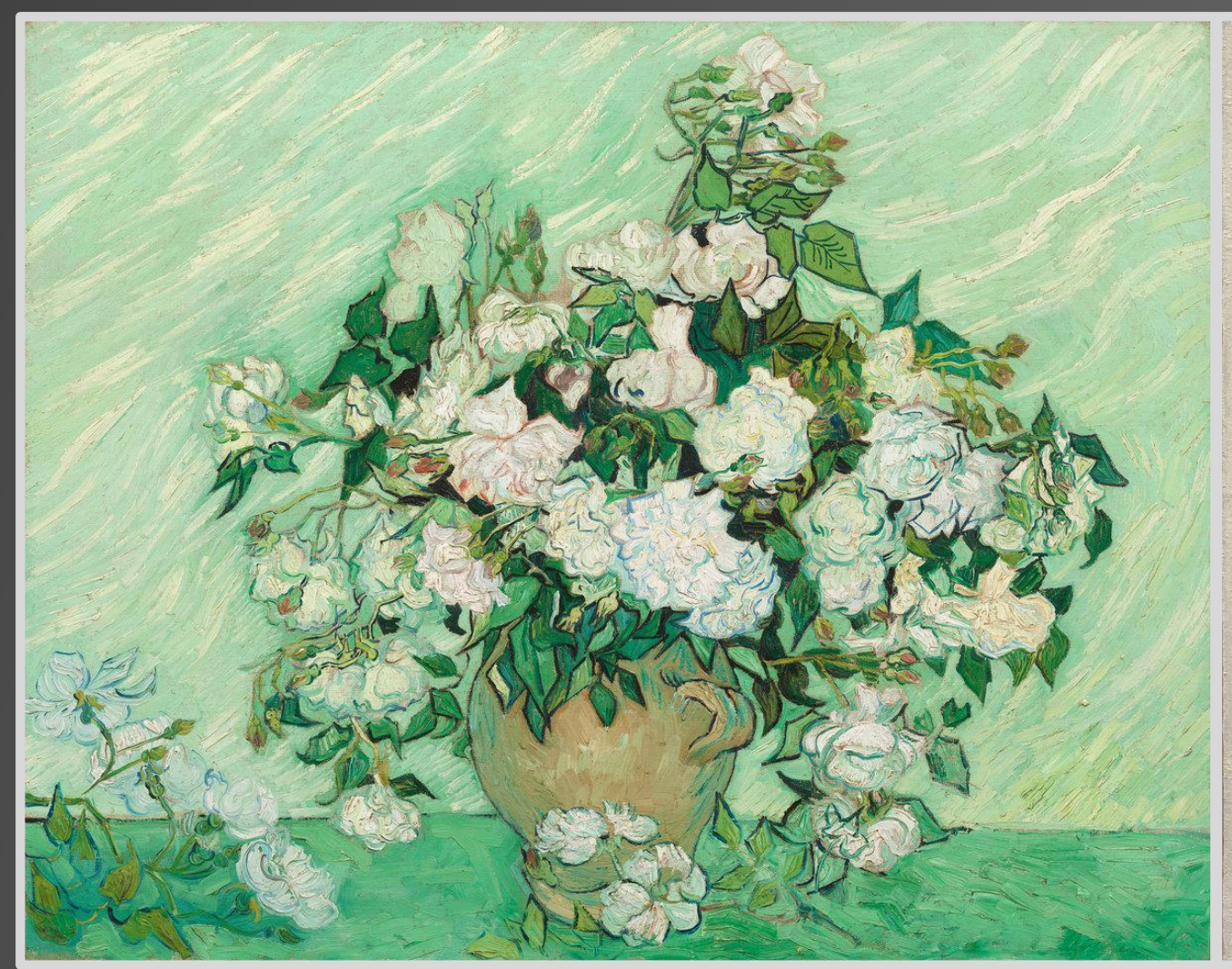

Public domain (NGA images)

Public domain (Wikimedia Commons)

work-level 


\section{Entity-level for colour content}

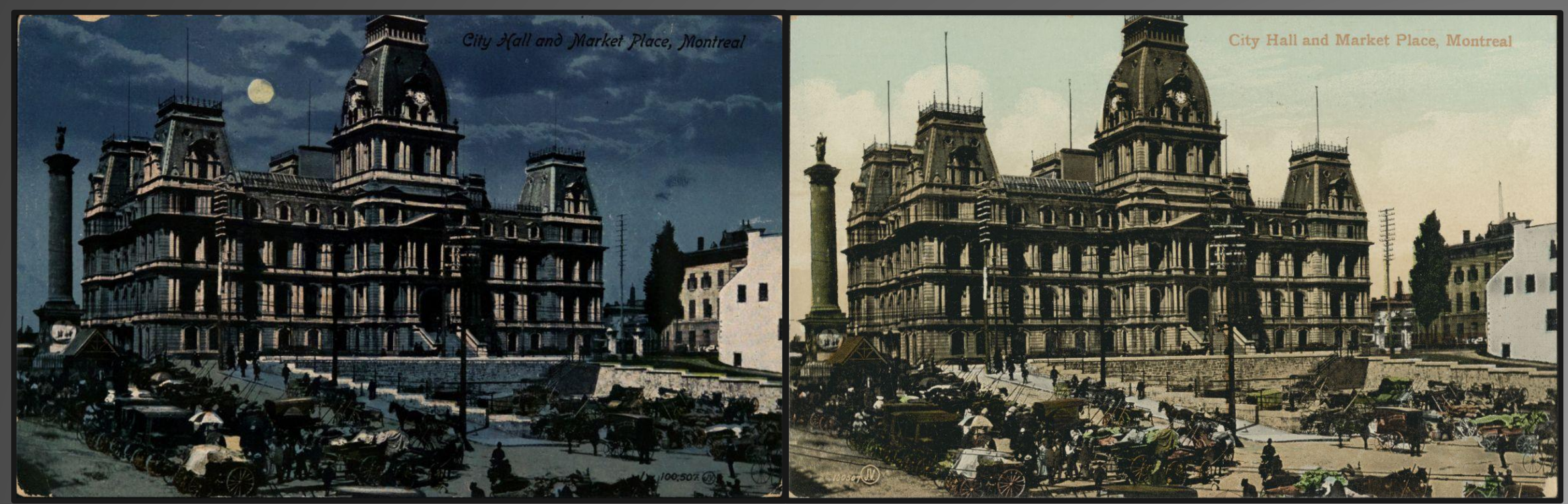

Public domain (BAnQ numérique)

instance-level 


\section{Entity-level for colour content}

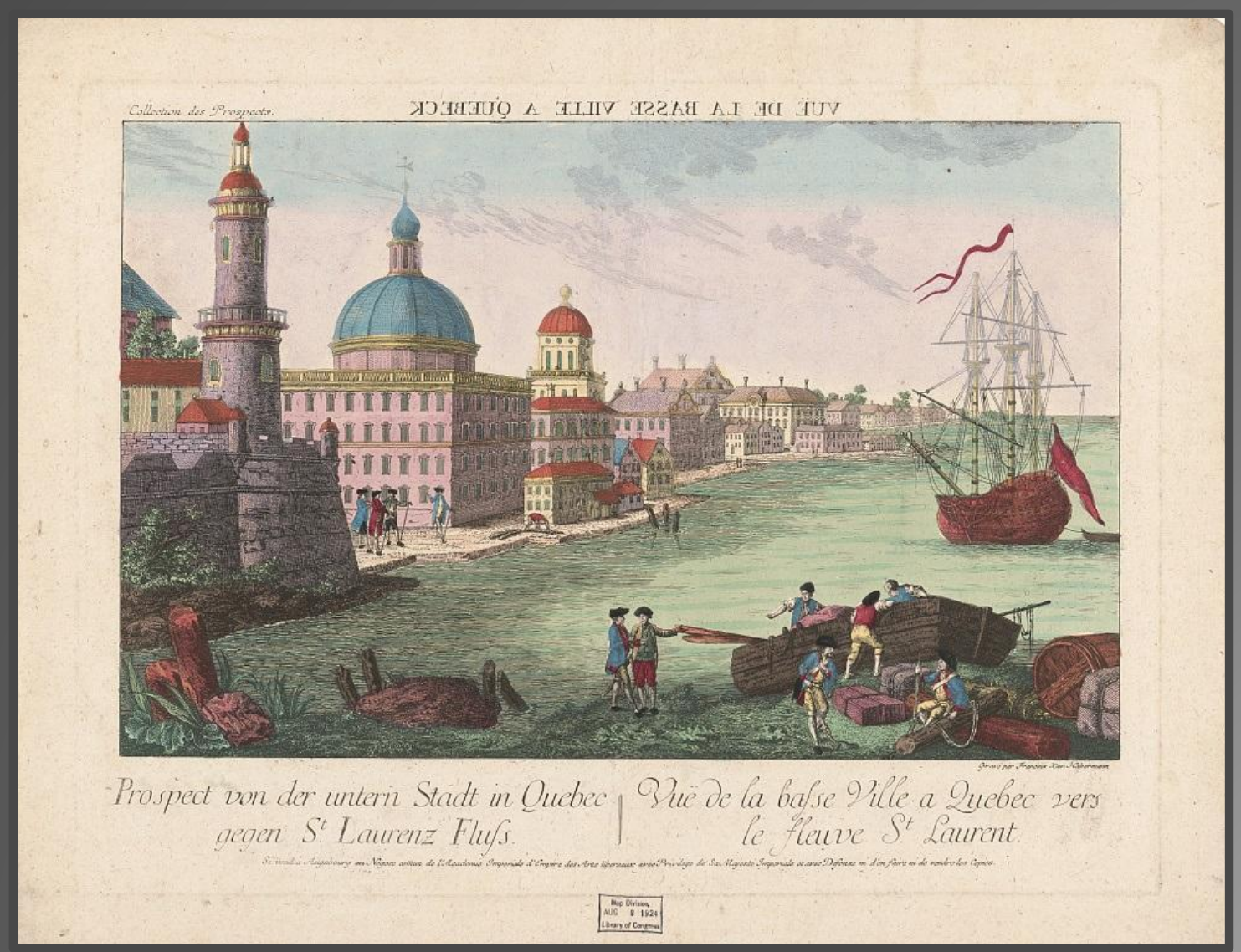

Public domain (BAnQ numérique)

item-level 


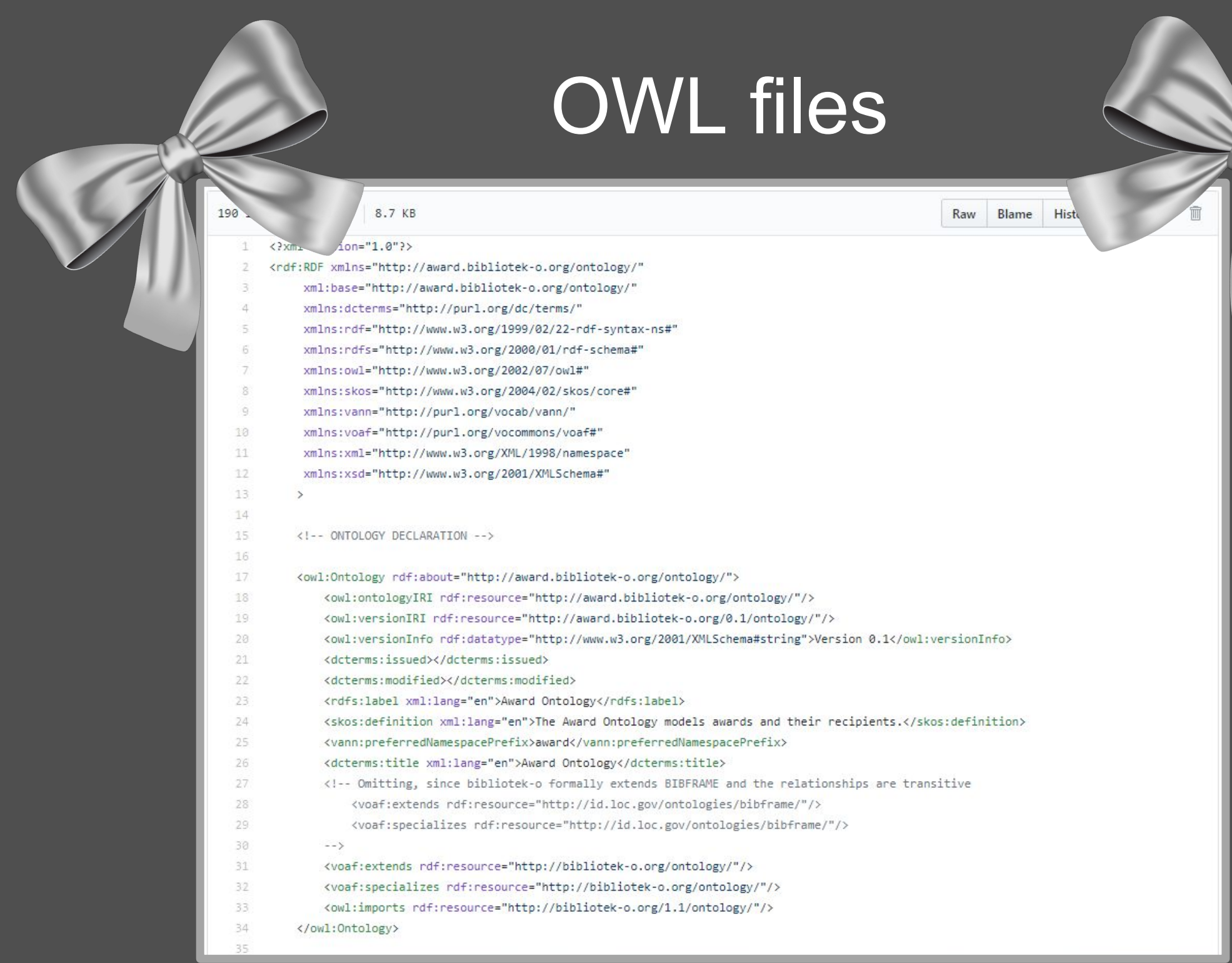

\section{Award model}




\section{Positive outcomes for the CAC}

- Opportunity to network (online and in-person meetings, special working groups)

- Hands-on experience of data modelling (tutorials and training sessions, reading materials, expertise of our colleagues)

- Clearer view of the future of structure standards for art information

- Occasion to have a real impact on the development of standards used by our community 


\section{Image credits}

Carpeaux, Jean-Baptiste. Neapolitan fischerboy. 1 sculpture : marble ; $92 \times 42$ x $47 \mathrm{~cm}$. Between 1857-1861. Source : NGA images (Samuel H. Kress Collection)

City Hall and Market Place, Montreal [night view]. 1 postcard : color collotype on cardboard; 9 x $14 \mathrm{~cm}$. Montreal : The Valentine \& Sons Publishing Co., Ltd., between entre 1903 et 1918.

Source : BAnQ numérique.

City Hall and Market Place, Montreal [daylight view]. 1 postcard : color collotype on cardboard 9 x 14 cm. Montreal ; Toronto : The Valentine \& Sons' Publishing Co., Ltd., between 1903 et 1908. Source : BAnQ numérique.

Gemito, Vincenzo. Bust of the fisherboy. 1 sculpture : bronze ; height $45 \mathrm{~cm}$. Model 1876?, cast between 1883 and 1886. Source : NGA images.

Habermann, Franz Xaver. Prospect von der untern Stadt in Quebec gegen St. Laurenz Fluss. 1 print : hand-coloured etching; sheet 38 × $48 \mathrm{~cm}$. Augsburg : s.n., between 1770 and 1779 . Source: BAnQ numérique.

Lordon, Pierre Jérôme. Atala et Chactas : A la clarté de la lune, j'entrevois une grande figure blanche penchée sur moi, occupée à dénouer silencieusement mes liens. 1 print : etching, black ink on wove paper ; image $33 \times 40 \mathrm{~cm}$, on sheet 41 x $48 \mathrm{~cm}$. Between 1801 and 1810. Source : BAnQ numérique.

Malevitch, Kasimir. White on white. 1 painting : oil on canvas ; 80 x 80 cm. 1918. Source : Wikimedia Commons (MoMA).

Runge, Philip Otto. “Die Farbenkugel”. In : Farben-Kugel oder Construction des Verhältnisses aller Mischungen der Farben zueinander, und ihrer vollständigen Affinität, mit angehängtem Versuch einer Ableitung der Harmonie in den Zusammenstellungen der Farben. Hamburg : Friedrich Perthes, 1810.

Van Gogh, Vincent. Roses. 1 painting : oil on canvas ; 71 x $90 \mathrm{~cm}$. 1890. Source : NGA images.

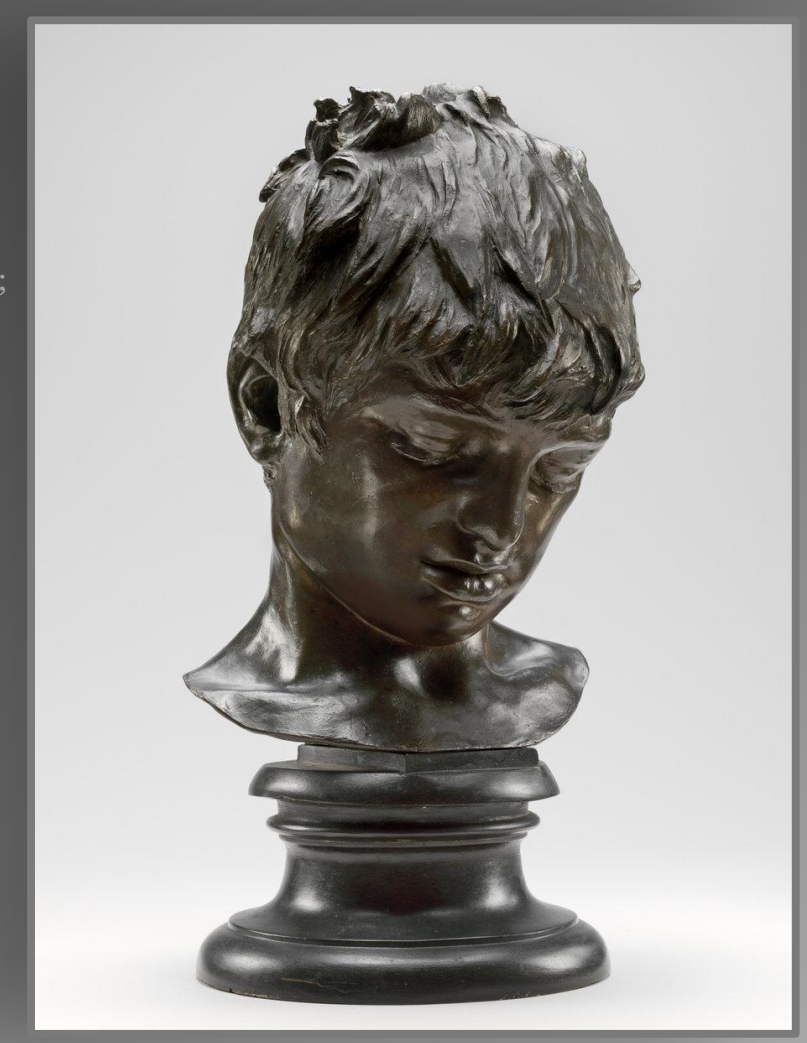

Public domain (NGA images) 


\section{Textual sources}

Baca, Murtha, and Sherman Clarke. "FRBR and works of art, architecture, and material culture". In Understanding FRBR : what it is and how it will affect our retrieval tools, edited by Arlene G. Taylor, 103-110. Westport, CT : Libraries Unlimited, 2007.

Baker, Tom, Karen Coyle, and Sean Petiya. "Multi-entity models of resource description in the semantic Web : a comparison of FRBR, RDA, and BIBFRAME", Library hi tech 32, no. 4 (2014) : 562-582,

DOI:10.1108/LHT-08-2014-0081

Cataloging Advisory Committee of the Art Libraries Society of North America. Review of the FRBR-Library Reference Model (FRBR-LRM). May 1, 2016.

http://arliscac.pbworks.com/w/file/fetch/107661712/FRBR-LRM_review.pdf Riva, Pat, Patrick Le Bœuf, and Maja Žumer. IFLA library reference model : a conceptual model for bibliographic information. The Hague, Netherlands : International Federation of Library Associations, 2017. https://www.ifla.org/files/assets/cataloguing/frbr-lrm/ifla-lrm-august-2017 rev201712.pdf

Thompson, Timothy A., Jennifer Baxmeyer, Joyce Bell, and Peter Green. "From notes to annotations : dedications as data in the library of Jacques

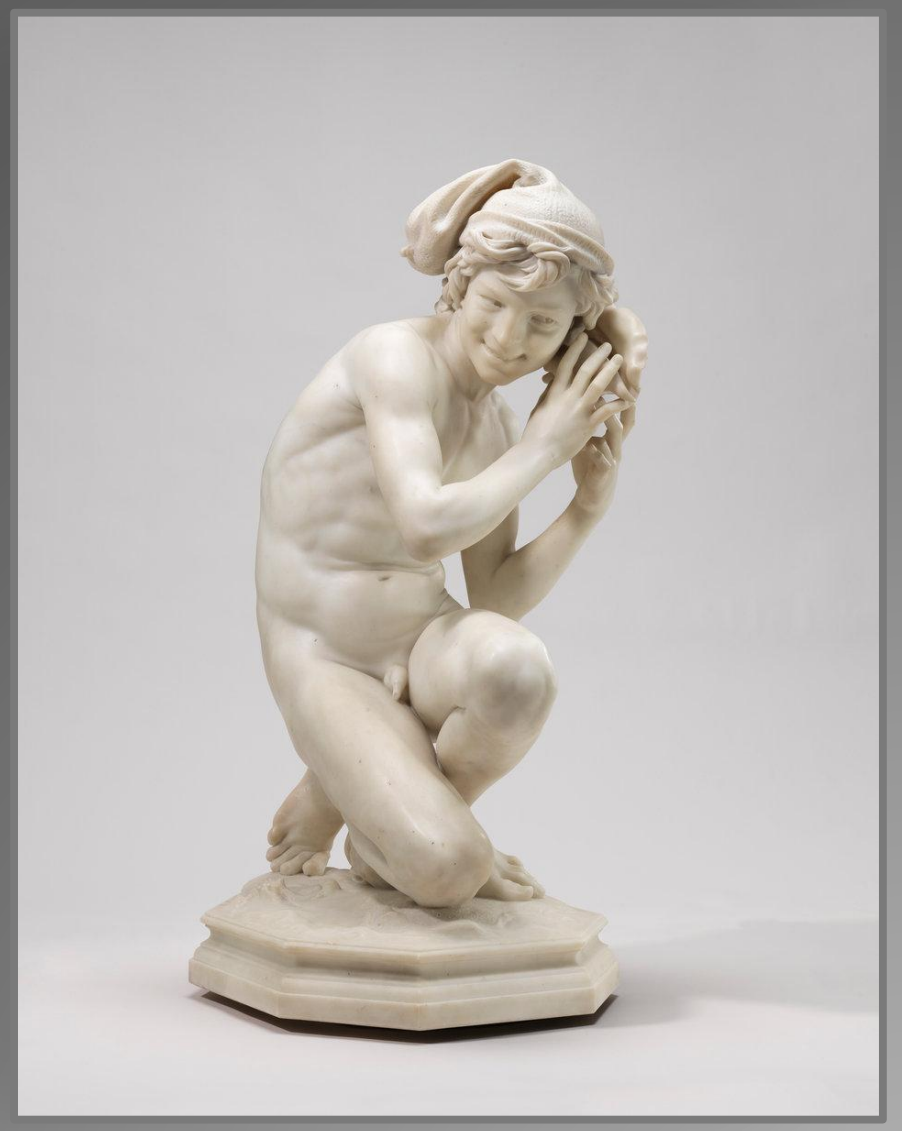

Public domain (NGA images) Derrida at Princeton University", Journal of library metadata 16, iss. 3-4 (2016) : 146-165, https://doi.org/10.1080/19386389.2016.1258908 